\title{
Cross-Border Investment and Financing Reforms in Shanghai Pilot Free Trade Zone ${ }^{1}$
}

\author{
Jin Wang \\ Financial Research Centre, Fudan University, Shanghai, China \\ Email: wangjin@fudan.edu.cn
}

Received 6 June 2016; accepted 20 June 2016; published 23 June 2016

Copyright (C) 2016 by author and Scientific Research Publishing Inc.

This work is licensed under the Creative Commons Attribution International License (CC BY). http://creativecommons.org/licenses/by/4.0/

(c) (i) Open Access

\begin{abstract}
In the past three years, Shanghai Pilot Free Trade Zone has taken a series of reforms on crossborder investment and financing, including implementing filing system of cross-border investment and financing, establishing split accounting management system, promoting RMB crossborder use and improving the degree of capital account convertibility. These measures have greatly improved the legal environment of cross-border capital flows and practically respected the autonomy of enterprises.
\end{abstract}

\section{Keywords}

Cross-Border Investment and Financing, Split Accounting Management System, RMB Cross-Border Use, Capital Account Convertibility

\section{Implementing Filing System of Cross-Border Investment and Financing}

Since Shanghai Pilot Free Trade Zone (FTZ) listed, the People's Bank of China (PBC), China Banking Regulatory Commission (CBRC), China Securities Regulatory Commission (CSRC), China Insurance Regulatory Commission (CIRC) and Shanghai Municipal People's Government have introduced a series of policies and regulations of supporting cross-border investment and financing reform around serving real economy development and respecting the autonomy of enterprises, which have driven innovation of financial system in this field and gradually promoted a lot of relevant experience across the country.

In order to further expand opening up, promote the reform of overseas investment management system and create an international and legal investment environment, according to China (Shanghai) FTZ Overall Program (hereinafter referred to as Program), FTZ introduced "China (Shanghai) FTA Overseas Investment Project

\footnotetext{
${ }^{1}$ This is the Periodical results of research project "Effective Framework for The Resolution of Systemically Important Financial Institutions
} and China's Strategies" (2014M561391) which the author charged. 
Record Management Rules", "China (Shanghai) FTZ Foreign Investment Enterprises Record Management Rules", "China (Shanghai) FTZ Overseas Investment Establishing Enterprises Record Management Rules", "China (Shanghai) FTZ Foreign Investment Access Special Management Measures" (Negative List) (2013) and "China (Shanghai) FTZ Foreign Investment Projects Record Management Rules". Cross-border investment and financing filing system are implemented in FTZ.

Before the establishment of FTZ, corporation's cross-border M \& A should complete approval and registration procedures with NDRC, Ministry of Commerce and SAFE. Especially, state-owned enterprises (SOE) needed to complete relevant procedures with State-owned Assets Supervision and Administration Commission (SASAC) first. The entire process usually takes 6 months. After implementing record system, enterprises only need to submit application materials to the Administrative Committee. The functions of National Development and Reform Commission (NDRC) and Business Commission are flowed within the Administrative Committee, making the entire process shorten to 5 working days. After 7 days, enterprises can get "Overseas Investment Certificate" and settle exchange through bank records directly, so that time cost, money cost and psychological burden are alleviated significantly; cross-border investment and financing facilitation are more convenient. From a legal perspective, by the following management rules, FTZ Administrative Committee changes from approval system to filing system for overseas investment and foreign enterprises domestic investment. The Administrative Committee supervises enterprises' overseas investment and financing behavior and foreign enterprises' domestic investment and financing behavior in the course and afterwards. The change reflects the transformation of government management thinking, innovation of management style and the self-discipline of government executive power, thus contributing to the formation of "tolerant entry and strict control" market environment.

As the pioneer of reforming cross-border investment and financing management system, FTZ creates a new supervisory model of "filing-based, approval-supplemented" and it now carries out outside the FTZ. It successfully explains the "nursery" function of FTZ. Based on the convenience of cross-border M \& A investment and financing convenience, on April 8th, 2014, NDRC issued "Overseas Investment Projects Approval and Record Management Rules" that is NDRC Command No. 9, which released overseas investment projects' approval and filing management rules; on April 16th, Ministry of Commerce issued "Overseas Investment Management Rules" (Revised) (Exposure Draft); SAFE introduced relevant policies soon afterwards. The core of the above rules and policies is "streamline administration and institute decentralization". Unless involving sensitive countries, regions and industries which need examination and approval by the State Council Department, filing system can apply to all investment abroad, regardless of amount. Above measures will further promote and develop overseas investment and improve the level of foreign investment facilitation.

\section{Establishing Split Accounting Management System}

\subsection{Relevant Policies and Regulations}

December 2, 2012, the central bank issued a "Recommendation on Financial Support to the Construction of the Free Trade Zone of China (Shanghai)" (hereinafter referred to as "PBC Financial 30 articles"). (Shanghai, 2013) including the general principles, there are seven parts and thirty recommendations in "PBC Financial 30 articles". In the second part, "Innovate the account system which is conducive to risk management", PBC for the first time clearly stated the concept of split accounting management of free trade accounts in domestic and foreign currency for residents and non-residents, as well as the concept of split accounting unit for financial institutions. Its fifth article points out that the funds between free trade accounts of residents and any of offshore accounts, domestic but out-of-zone non-resident accounts, non-resident free trade accounts and other free trade accounts of residents can be freely transferred. To further strengthen the support for cross-border investment and financing activities in FTZ and to promote the development of real economy, according to "PBC Financial 30 articles", PBC Shanghai Headquarters issued "The Rules for Implementation on Split Accounting Businesses of China (Shanghai) Pilot Free Trade zone" (hereinafter referred to as "Rules for Implementation on Businesses") (Du, 2011) and "The rules of Prudential Management on the Risk of Split Accounting Businesses of China (Shanghai) Pilot Free Trade zone" (hereinafter referred to as "Prudent Management Rules") (Luo, 2008), which have been approved by the PBC. The Rules for Implementation on Businesses focus on the conduct of split accounting businesses in FTZ and relevant requirements, which specify the specific requirements on the establishment of split accounting management system in financial institutions of Shanghai area as well as the opening of free trade accounts, the use and management of funds and so on. According to the requirements of ma- 
cro-prudent management and risk prevention and control, the Prudent Management Rules have made clear stipulations on prudent eligibility criteria of split accounting business management in FTZ, conformity assessment and acceptance about prudent eligibility of businesses, risk management, monitoring and warning on abnormal flows of funds and a variety of temporary regulatory measures. These two rules comprehensively normalized the split accounting businesses in FTZ as well as prudent management on risks and jointly built a accounting system framework which is in favor of the risk management of FTZ, laying the foundation for further promoting the businesses of investment and financing as well as exchange in FTZ in the next step. The implement of these two rules marks that the policy framework in "PBC Financial 30 articles" which is conducive to the accounting system of risk management has been basically formed, which provides important carrier and tool for trying and acting the financial reform of capital account convertibility in advance in FTZ.

\subsection{Content and Significance}

On the basis of retaining now existing RMB accounts and foreign exchange accounts, enterprises in FTZ can set up free trade accounts of domestic and foreign currency according to their own business operation needs, realize split accounting management and conduct various innovative businesses which are mentioned in "PBC Financial 30 articles", including handling cross-border fund settlement under current and direct investment accounts and investment, financing and exchange activities. These accounts can transfer funds freely with foreign offshore accounts, domestic but out-of-zone non-resident accounts and other free trade accounts; they can also transfer funds with out-of-zone general settlement accounts for the needs of current account businesses, credit repayment, industrial investment and other eligible cross-border transactions (regard as cross-border funds transferring management). Inside-zone enterprises can use their free trade accounts to conduct the businesses of cross-border financing and guarantee activities, when conditions are ripe, domestic and foreign currency funds inside the accounts can be freely exchanged. Since such free trade accounts can freely transfer funds with offshore accounts, when inside-zone enterprises use the funds in these accounts to make external loans or overseas loan under domestic guarantee for their invested overseas enterprises, they will not be limited by the tedious and mutually conflicting administrative licensing procedures outside the zone. And since the use of funds will be transited from advance auditing to post-supervision, the service efficiency and degree of speediness will be largely raised, which will bring large convenience for the cross-border financing activities of inside-zone enterprises. Not restricted to financial institutions in FTZ, all the financial institutions of Shanghai region can establish free trade accounting system according to the requirements. In the meantime, institutions that establish free trade accounts in FTZ will not be restricted bank institutions, nonbanking entities like securities, insurance, etc., can also conduct free trade accounts according to the detailed rules. Overseas enterprises can also open non-resident free trade accounts in the banks inside FTZ and can enjoy relevant financial service according to the principle of Post-Establishment National Treatment. Free trade accounts started in June 2014, and expanded cross-border financing scale and channels of enterprises in February 2015, and foreign currency service of free trade accounts started in April.

Establishing free trade accounts system and implementing split accounting management are important institutional arrangements in exploring investment, financing and exchange convenience, expanding opening of financial market as well as guarding against financial risks by FTZ. It is also the core of experimentally propelling capital account convertibility according to overall steps of the country by Shanghai government (People's Bank of China, 2015). It means that there is a fund flow system respectively inside and outside the zone and they can mutually connect with each other, which shows that fund flow regulations tend to lose inside and outside zone as well as that initiatives for cross-border investment and financing of enterprises are released. Relying on the carrier of free trade accounts, inside-zone entities can actively conduct innovative businesses like investment, financing, exchange etc.; relevant departments can utilize this carrier and tool, according to the general principle of "promote when matures", to separately set implementing measures and actively promote reform experiments of individual cross-border investment, capital market opening, facilitation of cross-border financing. Furthermore, relevant departments can improve environment of business in FTZ to better satisfy the demands of real economy to financial services, promoting FTZ to participate in international competence on a higher platform. Generally speaking, through the split accounting and individual accounting of banks, whose service objects include insider-zone residents along with overseas non-residents, we substantially build a financial environment which includes onshore and offshore business, integrate domestic and foreign currency and is highly in line with 
international financial market.

\section{Promoting RMB Cross-Border Use}

The "Program" put forward, "Under the premise of risk control, create conditions for the first test of RMB capital account convertibility, interest rate liberalization, RMB cross-border use and other aspects in FTZ" (People's Bank of China, 2014), which determines the general direction of RMB cross-border use. On this basis, "PBC Financial 30 articles" identifies the specific objectives on pilot financial reform, such as exploring investment and financing exchange facilities, expanding RMB cross-border use, promoting interest rate liberalization steadily and deepening foreign exchange management reform. Specifically, the business on cross-border RMB clearing under current account, direct investment, as well as the restrictions on borrowing RMB from abroad were substantially liberalized; institutions and individuals inside were allowed to invest domestic securities; and overseas parent companies of enterprises inside were allowed to issue RMB bonds in the domestic capital market. On Feb. 21, 2014, PBC Shanghai Headquarters issued "Notice on Supporting FTZ to Expand RMB Cross-Border Use" (hereinafter referred to as "Notice"), which makes specific standards for RMB overseas loan, two-way RMB capital pool, cross-border RMB centralized payment and personal cross-border RMB business. On Oct. 30, 2015, PBC, the Ministry of Commerce, CBRC, CSRC, CIRC, FX Bureau and Shanghai Municipal People's Government jointly released "Program to Further Promote Pilot Financial Open Innovation in SFTZ and Speed up the Construction of Shanghai International Financial Centre" (hereinafter referred to as "Financial Reform 40 articles") (Shang, 2014). The program further emphasized the need to expand RMB offshore use, to promote trade, industrial investment and financial investment, to move forward the capital and RMB "going out". According to "PBC Financial 30 articles", "Notice" and "Financial Reform 40 articles", the highlights on promoting RMB cross-border in the following 4 points:

Firstly, simplifying cross-border RMB settlement: 1) Cross-border RMB Settlement under current account and direct investment in FTZ are more convenient. On the basis of the following principles: "know your customers", "know your business" and "due diligence", Shanghai regional banks can handle cross-border RMB settlement business of direct investment under current account, with simply collection and payment instructions submitted by institutions and individuals inside; 2) Make sure that individuals can apply for cross-border RMB settlement business under current account. Individuals employed or practising inside can open personal bank settlement accounts or individual-owned business unit settlement accounts, for handling cross-border RMB collection and payment business under current account; 3) within the scope of the license (including Internet payment), Shanghai regional banks can cooperate with those inside institutions who has Payment Business License, to provide RMB clearing and settlement services for cross-border e-commerce (trade in goods or trade in services).

Secondly, allowing RMB overseas borrowing. Corporative enterprises registered in FTZ can borrow RMB funds from abroad no more than the amount of double paid-up capital for their own business purposes. The above-mentioned rules break the privileges of foreign-funded enterprises and make an institutional arrangement for Chinese enterprises to obtain debt assets, so that companies arrange the proportion of equity and debt reasonably according to their financial needs and reduce financial costs effectively (People's Bank of China, 2014). Funds of cross-border RMB borrowed off shore can be used for real economic purposes including production, operation and projects in FTZ as well as projects overseas. Domestic companies can make use of overseas resources, facilitate cross-border financing, reduce financing costs and achieve better international cooperation and competition.

Thirdly, supporting foreign institutions to issue RMB bonds. Under the framework of macro-prudential and micro-prudential principles, FTZ will simplify the administrative procedures, gradually expand the types of domestic inter-bank bond market for foreign institutional investment, steadily increase the scale of investment and gradually relax the restrictions for domestic institutions issuing RMB bonds overseas. By allowing international financial institutions to issue debt in our domestic market, Chinese government has shown a positive attitude on opening up capital market steadily, resulting in the expansion of China's influence in the international capital market, improving China's sovereign rating, as well as Chinese enterprises rating and reducing our financing costs in the international market.

Fourthly, establishing two-way cross-border RMB fund pool. When enterprises do cross-border business, internal capital transactions in a group which has domestic and foreign equity are inevitable. If FTZ management 
committee wants to attract global or regional headquarters of multinational enterprises, especially introduce some important management functions into the zone, to promote the transformation and upgrading of industrial structure of this area, it is necessary to pay attention to objective demands from the real economy. By conducting two-way cross-border RMB fund pool business, enterprise can use domestic funds for investment and operations abroad more conveniently, and avoid the local financing difficulties when a new foreign enterprise was established; Meanwhile when business branches around the world exist temporary funding wealthy, it can be moved into the group headquarters to manage. This greatly improves the scale effect of group fund, the financial capacity of logistics and capital efficiency. Today, cross-border RMB fund pool has been put forward to the whole country in 2014, but enterprises inside still have more benefits to launch two-way cross-border RMB fund pool trade enterprises compared to outside enterprises, such as lower threshold, higher amount, etc.

\section{Improving the Degree of Capital Account Convertibility}

In the past, China has adopted strict control on the capital account and the company's cross-border financing has been heavily regulated. Only Foreign-funded enterprises has been allowed to borrow foreign loans within the difference between investment and registered investment while the maximum amount of foreign exchange purchasing for an individual resident is only $\$ 50,000$ per year. At the same time, strict capital controls resulted in a huge gap between the price of domestic and foreign funds, and severely limited convenience of the cross-border investment and financing as well (People's Bank of China, 2015). At the end of 2013, the Third Plenary Session of the Eighteenth Central Committee of the CPC clearly made a claim for "accelerating the process of capital account convertibility". To this end, "PBC Financial 30 articles" and "Financial Reform 40 articles" both stressed the need to improve the degree of capital account convertibility and made relevant regulations at great length. Specifically, "Financial Reform 40 articles" pointed out that the pilot program of RMB capital account convertibility in FTZ should be implemented according to the principles, including overall planning, serve entities, controllable risk and step by step. The completed reform and the focus of future advance are mainly reflected in the following three aspects:

Firstly, summarizing the experience of free trade account. The pilot program of RMB capital account convertibility in FTZ should mainly rely on the free trade account system, which will help prevent and control financial risks. The financial account, which is an electronic fence, is able to provide convenience of cross-border capital flows and well balance the relationship between financial openness and risk prevention by making capital flows monitorable and traceable. The next step is to continue to support economic agents to carry out foreign trade and investment activities through the free trade account, encourage and support financial institutions refer to banking, securities and insurance to do financial innovation business on the free trade account, allow securities and futures exchanges to take full advantage of the electronic information flow and capital flow between free trade accounts and study reform and innovation action around the free trade account system, launch a business process of integration of domestic and foreign currencies through free trade accounts, expand the function of these accounts, gradually increase the degree of capital account convertibility and make it more convenient for enterprises and individuals to carry out domestic and overseas investment and financing activities.

Secondly, relaxing controls over individual's overseas investment. For a long time, since the policy constraint, the policy of individual overseas investment is "partial open, limited outflow". Lawful and compliant investment channels are quite limited. Generally, domestic individual investors choose to invest abroad by "playing the edge ball", which has brought great difficulty for regulators. (Yin, 2014) the FTZ justifies natural person's foreign investments. Article 9 in "PBC Financial 30 articles" lays down a set of requirements: allowing qualified individuals who work in the zone to invest aboard, including investment securities; make external payments after paying income taxes; individual businesses in the zone can provide overseas business entities with cross-border lending according to their business needs; qualified foreign individuals who work in the zone are allowed to open domestic investment accounts for non-resident individuals and invest aboard including investment securities according to regulations. In this clause, individuals are allowed to make securities, futures, funds and other investments on the international capital markets in the zone by using personal income. It means that individuals in the zone will no longer restricted by QDII. In addition, Article12 "offering a variety of risk hedging instruments" means that qualified enterprises in the zone are allowed to carrying out business including overseas securities and derivatives investments according to the regulations. This can also be understood as the current QDII quota fully liberalized, and will be extended to derivatives, which are aimed for better risk hedging 
rather than speculating. "Financial Reform 40 articles" provides that FTZ will conduct the research, launch the pilot of allowing qualified domestic individual investors to invest overseas, and timely introduce the detailed rules of allowing qualified individuals to carry out foreign industrial investment, real estate investment and financial investment. relaxing controls over individual's overseas investment, firstly, can regularize individuals' behavior of overseas investment which can fully protect the legitimate interests of the residents when investing overseas and help promote the "going out" of private capital; secondly, can help deepen financial reform and promote the "going out" of Chinese financial industry; thirdly, can effectively promote to achieve the "stockpile foreign exchange reserves in state coffers", ease the pressure brought by the growth of foreign exchange reserves and promote the balance of international payments. Meanwhile, with the increasing number of foreign investors, foreign banks can make use of their widely distributed overseas branches to better serve Chinese individual investors.

Thirdly, innovating the system of foreign exchange management. Currently, the policies of foreign exchange reform and innovation in the FTZ cover the main contents of the foreign exchange management, including current and capital items: the first is streamline administration and institute decentralization, actively promoting capital account convertibility, transferring the formalities of direct investment and foreign exchange registration to banks so that corporations do not need to go to the forex bureau to go through the foreign exchange procedures of direct investments; the second is further broadening the channels for capital outflow, relaxing management over foreign investments' upfront costs and domestic enterprises' overseas lending, improving the upfront costs' quota of domestic enterprises' overseas investment, relaxing controls over the limitation of domestic enterprises' overseas lending body and loan conditions; the third is conducting a pilot of the management of foreign-invested enterprises' foreign exchange capital willingness exchange settlement, which is the reform and innovation of current foreign exchange capital payment and settlement system, providing enterprises with policy space and effective means to avoid exchange rate fluctuations risk and giving enterprises entire decision-making right of foreign exchange capital settlement, effectively facilitating the development of the real economy. "Financial Reform 40 articles" points out that the next step is to explore the convertible pilot within the limits in FTZ; further innovate foreign exchange management system centered on the aim of building the free trade test site and Shanghai international financial center; relax controls over cross-border capital flows and perfect the equilibrium management system of foreign exchange funds; conduct an overall research of further expanding personal convertible quota; according to the principle of subject supervision, realize the convertibility of non-financial corporation's within the quota in the free trade test site; gradually expand the limits of the currency exchange and achieve convertibility initiatively. Considering the financial reform and capital account convertibility are sequential, the FTZ takes a strategy of promote one program when it is mature, considers the development needs and realities, focuses on prevention and control of risks, actively and steadily promotes capital account convertibility under this premise. The overall goal is to gradually increase the level of capital account convertibility.

\section{Conclusion}

Through all the innovations of FTZ financial service above, the financial institution can do a good job of financial services on trade facilitation and economic and trade rules establishment, in line with the latest international standards. These measures will significantly enhance liquidity, contribute to the introduction of more financial products, meet the world demand for RMB investment and further expand the trade settlement. But it should be clearly recognized that the current reform related to cross-border investment and financing is a preliminary framework, and we need to issue detailed rules for the implementation of the provisions so that policy can really land. The content of the clause also requires constant innovation with the development of local institutions' economic activities in FTZ. In this regard, PBC and the Shanghai government should continuously explore how to further enhance the FTZ's financial services, making it meet the institutions' requirements and providing identifiable ground for promoting the country's financial reform.

\section{References}

Du, P. (2011). The Current Situation and Characteristic of Cross-border Fund Flow in China. Journal of Shanghai Finance. 6, 11-12.

Luo, H. B. (2008) Mechanism of International Financial Capital Movement. Dissertation for Doctor Degree, 175-177. 
People's Bank of China (2014) Recommendation on Financial Support to the Construction of the Free Trade Zone of China (Shanghai). http://www.pbc.gov.cn/redianzhuanti/118742/118666/119015/119759/826333/index.html

People's Bank of China (2014) The Rules for Implementation on Split Accounting Businesses of China (Shanghai) Pilot Free Trade Zone.

http://www.china-shftz.gov.cn/PublicInformation.aspx?GID=54ceb30e-f6ab-4daf-9fdd-d87fec9f5f2e\&CID=953a259a-15 44-4d72-be6a-264677089690\&MenuType=1\&navType=1

People's Bank of China (2015) Program to Further Promote Pilot Financial Open Innovation in SFTZ and Speed up the Construction of Shanghai International Financial Centre.

http://www.pbc.gov.cn/goutongjiaoliu/113456/113469/2970998/index.html

People's Bank of China (2015) The Rules of Prudential Management on the Risk of Split Accounting Businesses of China (Shanghai) Pilot Free Trade Zone.

http://www.china-shftz.gov.cn/PublicInformation.aspx?GID=55920a24-96e3-485a-b064-4acaccba8a8e\&CID=953a259a-1 544-4d72-be6a-264677089690\&MenuType=1\&navType $=1$

Shang, R. (2014) The Establishment of Free Trade Account system in Shanghai FTZ: A New breakthrough of FTZ Policy. Journal of Shanghai Finance, 8, 4-5.

Shanghai (2013) Pilot Free Trade Zone Overall Program. http://www.gov.cn/zwgk/2013-09/27/content_2496147.htm

Yin, L. S. (2014) Thinking of Speeding-Up RMB Cross-Border Service and Opening Capital Account in Shanghai FTA. Journal of Scientific Development, 70, 19-20.

\section{Submit or recommend next manuscript to SCIRP and we will provide best service for you:}

Accepting pre-submission inquiries through Email, Facebook, Linkedin, Twitter, etc A wide selection of journals (inclusive of 9 subjects, more than 200 journals)

Providing a 24-hour high-quality service

User-friendly online submission system

Fair and swift peer-review system

Efficient typesetting and proofreading procedure

Display of the result of downloads and visits, as well as the number of cited articles

Maximum dissemination of your research work

Submit your manuscript at: http://papersubmission.scirp.org/ 